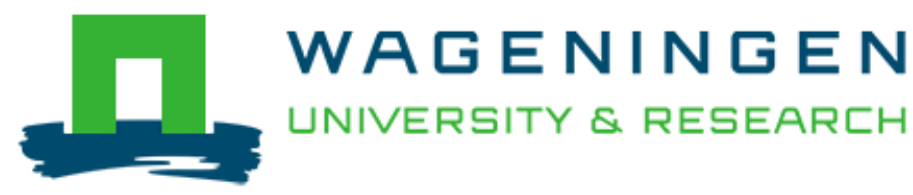

\title{
Environmental consequences of processing manure to produce mineral fertilizer and bio-energy
}

de Vries, J. W., Groenestein, C. M., \& de Boer, I. J. M.

This is a "Post-Print" accepted manuscript, which has been published in "Journal of Environmental Management"

This version is distributed under a non-commercial no derivatives Creative Commons (c) (1) (9) (CC-BY-NC-ND) user license, which permits use, distribution, and reproduction in any medium, provided the original work is properly cited and not used for commercial purposes. Further, the restriction applies that if you remix, transform, or build upon the material, you may not distribute the modified material.

Please cite this publication as follows:

de Vries, J. W., Groenestein, C. M., \& de Boer, I. J. M. (2012). Environmental consequences of processing manure to produce mineral fertilizer and bio-energy. Journal of Environmental Management, 102, 173-183.

https://doi.org/10.1016/j.jenvman.2012.02.032 


\title{
Environmental consequences of processing manure to produce
} mineral fertilizer and bio-energy ${ }^{1}$

\author{
J.W. De Vries ${ }^{\mathrm{a},}$, C.M. Groenestein ${ }^{\mathrm{a}}$, I.J.M. De Boer ${ }^{\mathrm{b}}$ \\ ${ }^{a}$ Wageningen UR Livestock Research, Wageningen University and Research Centre, \\ P.O. Box 135, 6700 AC, Wageningen, the Netherlands \\ ${ }^{\mathrm{b}}$ Animal Production Systems Group, Wageningen University, P.O. Box 338, 6700 \\ $\mathrm{AH}$, Wageningen, the Netherlands \\ *Corresponding Author: Tel.: +31 (0)320-238044; Fax: +31 (0)320-238094, E-mail \\ address: jerke.devries@wur.nl (J.W. De Vries).
}

\begin{abstract}
Liquid animal manure and its management contributes to environmental problems such as, global warming, acidification, and eutrophication. To address these environmental issues and their related costs manure processing technologies were developed. The objective here was to assess the environmental consequences of a new manure processing technology that separates manure into a solid and liquid fraction and de-waters the liquid fraction by means of reverse osmosis. This results in a liquid mineral concentrate used as mineral nitrogen and potassium fertilizer and a solid fraction used for bio-energy production or as phosphorus fertilizer. Five environmental impact categories were quantified using life cycle assessment: climate change (CC), terrestrial acidification (TA), marine eutrophication (ME), particulate matter formation (PMF), and fossil fuel depletion (FFD). For pig as well as dairy cattle manure, we compared a scenario with the processing method and a scenario with additional anaerobic digestion of the solid fraction to a reference situation applying only liquid manure. Comparisons were based on a functional unit of 1 ton liquid manure. System boundaries were set from the manure storage under the animal house to the field application of all end products. Scenarios with only manure processing increased the environmental impact for most impact categories compared to the reference: ME did not change, whereas, TA and PMF increased up to $44 \%$ as a result of $\mathrm{NH}_{3}$ and $\mathrm{NO}_{\mathrm{x}}$ emissions from processing and storage of solid fraction. Including digestion reduced CC by $117 \%$ for pig manure and $104 \%$ for dairy cattle manure, mainly because of substituted electricity and avoided $\mathrm{N}_{2} \mathrm{O}$ emission from storage of solid fraction. FFD decreased by 59\% for pig manure and increased $19 \%$ for dairy cattle manure. TA and PMF remained higher compared to the reference. Sensitivity analysis showed that $\mathrm{CH}_{4}$ emission from manure storage, $\mathrm{NH}_{3}$ emission during processing, and the replaced nitrogen fertilizer by the mineral concentrate were important parameters affecting final results. It was concluded that processing fattening pig and dairy cattle manure to produce mineral fertilizer increased overall environmental consequences in terms of CC (except for dairy cattle manure), TA, PMF, and FFD compared to current agricultural practice. Adding the production of bio-energy reduced $\mathrm{CC}$ and $\mathrm{FFD}$. Only when $\mathrm{NH}_{3}$ emission from processing was low and bio-energy was produced, overall equal or better environmental performance was

\footnotetext{
${ }^{1}$ This paper was submitted in revised form to the Journal of Environmental Management on 19-1-2012.
} 
obtained for TA and PMF. It was emphasized that real time measurements should be done to enhance the environmental assessment of manure processing technologies. Results of this study present the full environmental consequences of manure processing and key parameters affecting the environmental impact of manure management. Outcomes can be used for decision making and further tackling of environmental problems related to manure management.

Keywords: LCA; slurry treatment; fertilizer; anaerobic digestion; greenhouse gases; ammonia 


\section{Introduction}

The environmental impact from animal manure and its management (i.e., storage and application) has increased considerably through growth of livestock production worldwide. In the Netherlands, for example, national production of pig and dairy cattle manure increased from about 46 million tons in 1950 to 68 million tons in 2009 (CBS, 2011). Manure contributes to the following environmental impacts: acidification and particulate matter formation, mainly through volatilization of ammonia $\left(\mathrm{NH}_{3}\right)$ and nitrogen oxides $\left(\mathrm{NO}_{\mathrm{x}}\right)$; climate change through emissions of greenhouse gases (GHG); eutrophication, mainly through leaching of nitrate $\left(\mathrm{NO}_{3}{ }^{-}\right)$ and phosphate $\left(\mathrm{PO}_{4}{ }^{3-}\right)$ to soil and surface water; and depletion of fossil energy sources as a result of management (Prapaspongsa et al., 2010; Sandars et al., 2003;

Thomassen et al., 2008).

These environmental impacts have led to international and national regulations (e.g., Gothenburg Protocol, NEC-Directives, and Nitrates Directive) designed to reduce emissions related to animal manure and management. This has induced surpluses in several regions of the world including the Netherlands, increasing manure removal costs for farmers. To decrease these costs and the environmental impact, manure processing technologies have been developed, including anaerobic digestion (AD), biological treatment, composting, incineration, and gasification (Burton and Turner, 2003). These technologies were mainly developed to reduce GHG emissions, $\mathrm{NH}_{3}$ volatilization and fossil fuel depletion by producing bio-energy. However, the whole life cycle of these technologies, including the storage and application of end products should be addressed to evaluate their true environmental performance.

The environmental impact of manure processing technologies has been analyzed along the entire life cycle of the manure and its end products by means of life cycle assessment (LCA) in several studies (Hamelin et al., 2011; Lopez-Ridaura et al., 2009; Prapaspongsa et al., 2010). GHG emissions were reduced through AD of manure as a result of bio-energy production (electricity and heat) and the substitution of mineral fertilizer. Reductions by up to $147 \mathrm{~kg}$ carbon dioxide equivalents ( $\mathrm{CO}_{2}$-eq.) per ton of pig manure and $104 \mathrm{~kg} \mathrm{CO}_{2}$-eq per ton of solid fraction of separated pig manure were reached through AD (Hamelin et al., 2011; Prapaspongsa et al., 2010). Acidification and eutrophication potentials did not vary, or very little, when digestion was applied. On the other hand these potentials have been shown to be increased 
through aeration of the liquid fraction from separated manure combined with composting of the solid fraction (Lopez-Ridaura et al., 2009).

A manure processing technology using liquid and solid separation and reverse osmosis (RO), currently being developed and investigated in the Netherlands, aims at producing a liquid nitrogen $(\mathrm{N})$ and potassium $(\mathrm{K})$ concentrate. The process produces as main products: mineral concentrate (MC), considered to have similar fertilizing properties as mineral $\mathrm{N}$ and $\mathrm{K}$ fertilizer, and a solid fraction that can be used as a substrate for $\mathrm{AD}$ and as a phosphorus (P) fertilizer. Although LCA studies have focused on the environmental impact of some manure processing technologies, the impact of this process has not been investigated.

The objective of this study was to assess the environmental impact of this new manure processing method for fattening pig and dairy cattle manure, and to compare it to conventional manure management practices. We used LCA to determine and compare the environmental impact of manure processing to produce mineral fertilizer, with and without $\mathrm{AD}$, including the application of its end products and compared it to current agricultural practice. 


\section{Materials and methods}

\subsection{LCA approach and functional unit}

Life cycle assessment is a method to determine the environmental impact of a system providing a product or service. An LCA includes all pollutants and consumptions of finite resources from each stage in the life cycle, and allows a comparative analysis of the environmental impact of different production scenarios of a product (ISO-14040, 2006). In particular, the LCA in this study aimed at assessing the environmental consequences of moving to a manure management system including manure processing relative to a reference without processing. We, therefore included in the analysis the change in environmental impact of all processes (also called marginal processes or suppliers) affected by this change in manure management (Weidema et al., 1999).

For a comparative assessment, the environmental impact is related to a functional unit (FU) that expresses the function of the system in quantitative terms. The function of the system is to process liquid manure into a MC that can be applied as mineral $\mathrm{N}$ and $\mathrm{K}$ fertilizer and a solid fraction suitable for bio-energy production or as $\mathrm{P}$ fertilizer. As the available manure was the starting point, a functional unit (FU) of 1 ton untreated liquid fattening pig or dairy cattle manure was applied. The same chemical composition of manure was applied in the references and the scenarios. This ensured that in all cases equal amounts of nutrients and dry matter were introduced into the system.

\subsection{Manure management system and scenarios}

\subsubsection{System boundaries}

The LCA included the environmental impacts from manure storage in the animal house and outside storage; processing of manure; storage, distribution, and field application of the end products; and the transport of materials between different life cycle stages (Fig. 1). To assess distribution and transport distances, we distinguished between four locations for product application: local application on a dairy farm with grassland, local application on an arable or dairy farm with arable land, external (i.e. off farm) application on an arable farm, and application on an arable farm outside the 
Netherlands. The system further included environmental impacts related to production of chemicals used for processing (e.g., flocculants), consumed electricity, and substituted electricity in the case of bio-energy production. The system boundaries also encompassed impacts from the production, transport, and application of avoided mineral fertilizer, i.e., $\mathrm{N}, \mathrm{P}$ and $\mathrm{K}$ avoided from mineral fertilizer as a result of using nutrients from manure. The analysis further included environmental emissions and resource use from the production of capital goods except for the manure storage and processing plants.

The system excluded the impacts from animal production, as we assumed that a change in the animal production sector would not be driven by a change in manure management. Additionally, biogenic $\mathrm{CO}_{2}$ emissions were not incorporated in the calculations as they are considered to be short cyclic carbon taken up by crops (IPCC, 1997). The emission of $P$ was excluded because manure processing was assumed to not affect the total amount of $\mathrm{P}$ in manure and end products. Input of $\mathrm{P}$ to the soil and crop, therefore, was the same for all references and scenarios.

Marginal products for mineral fertilizer production were assumed to be: ammonium nitrate for $\mathrm{N}$, triple superphosphate for phosphorus pentoxide $\left(\mathrm{P}_{2} \mathrm{O}_{5}\right)$, and potassium chloride for potassium oxide $\left(\mathrm{K}_{2} \mathrm{O}\right)$. Marginal electricity production was based on current Dutch statistics and EU production outlooks from the International Energy Agency. The long term marginal electricity source for the Netherlands was estimated to be a mix of coal (28\%), natural gas (67\%), and wind (5\%) (IEA, 2008, 2011). The utilization of excess heat from $A D$, i.e. heat produced in addition of the required heat for the process, was not included as heat offset possibilities are still limited in the Netherlands (Dumont, 2010).

\subsubsection{Manure processing}

Manure processing was done in five full-scale pilot plants operating in the Netherlands (Hoeksma et al., 2011). These pilot plants processed up to 50,000 tons of manure annually and aimed at producing a concentrated $\mathrm{N}-\mathrm{K}$ liquid and a remaining solid fraction mainly through three processing steps: 1 . separation of solids and liquids by means of dissolved air floatation, 2. separating the liquid from the solid remains by a sieve belt press or a screw press, and 3. de-watering of the effluent with reverse osmosis (Fig. 2). The plants produce three end products: MC, solid fraction, 
and permeate, i.e., water remaining after reverse osmosis. The $\mathrm{MC}$ and solid fraction were applied in crop production as fertilizers. The solid fraction was also used as a substrate for AD to produce bio-energy where after it was applied. Permeate was treated in a water purification plant and discharged to surface water (Fig. 1).

\subsubsection{Definition of scenarios}

For processing pig and dairy cattle manure, we compared the environmental impact of four scenarios relative to two reference situations. A reference for pig (PRef) as well as dairy cattle manure (CRef) was considered because their manure management systems differ considerably (Table 1). Furthermore, manure from fattening pigs was considered for the pig manure scenarios as this is the most common type of pig manure in the Netherlands.

The scenarios represented central processing plants. Scenario 1 implied processing of fattening pig or cattle manure into MC, solid fraction and permeate (PSc1 and CSc1), whereas scenario 2 also included AD of solid fraction to produce bio-energy (PSc2 and CSc2, Table 1).

Manure was stored for an average period of three months in the animal house in PRef and CRef. Additionally, in PRef, pig manure was stored for one month in a covered outside storage tank, which was excluded in PSc1 and PSc2 because manure processing reduced the need for storage space given that manure is collected from the farms on a monthly basis (De Vries et al., 2011). The end products were stored for a period of three months in a covered circular concrete tank, except for the solid fraction, which was stored in an open shed. They were then applied to the field (Table 1). All emissions and resource use for the processes were included in the assessment.

\subsection{Life cycle data inventory and assumptions}

\subsubsection{Chemical composition of manure and end products}

The chemical composition of manure after storage (Table 2) was based on KWIN (2009-2010) and corrected for emissions from the storage system to obtain the composition after excretion following a mass balance approach. Distribution of mass and nutrients to the end products was based on data from the pilot plants (Table 2). Data used for pig manure were also used for cattle manure. 


\subsubsection{Storage of manure and end products}

Emission of nitrogen occurred from manure and product storages as $\mathrm{NH}_{3}$, nitrous oxide $\left(\mathrm{N}_{2} \mathrm{O}\right)$, nitrogen monoxide (NO) and nitrogen gas $\left(\mathrm{N}_{2}\right)$ (Table 3). Emissions of $\mathrm{NH}_{3}$ from processing and storage of end products was estimated as two times the emission from manure storage (total $4 \% \mathrm{~N}$; $2 \%$ of $\mathrm{N}$ entering the processing plant and $2 \%$ of $\mathrm{N}$ during storage). A higher emission was assumed as a result of more contact area with outside air during processing and storage of end products. Emissions of $\mathrm{N}_{2} \mathrm{O}$, NO and $\mathrm{N}_{2}$ from storage of MC were not included as they were considered to be negligible (Mosquera et al., 2010). Emission of $\mathrm{N}_{2} \mathrm{O}$ from storage of solid fraction was based on solid manure storage (Groenestein et al., 2011). Leaching of $\mathrm{NO}_{3}{ }_{3}, \mathrm{P}$ and $\mathrm{K}$ during storage was assumed to be negligible because it is obligatory to have sealed concrete floors in manure and product storage systems in the Netherlands. Indirect emissions of $\mathrm{N}_{2} \mathrm{O}$ were included as $1 \%$ of $\mathrm{NH}_{3}-\mathrm{N}+\mathrm{NOx}-\mathrm{N}$ and $0.75 \%$ of $\mathrm{NO}_{3}-\mathrm{N}$ after application (IPCC, 2006a).

Emission of methane $\left(\mathrm{CH}_{4}\right)$ occurred during storage of manure and of end products. Methane emission from manure storage prior to processing was modeled specific to the conditions of this study (De Mol and Hilhorst, 2003); the modeled data captured changes in emission related to changes in manure storage retention time between the references (3 months) and the scenarios (1 month) (De Vries et al., 2010). Methane emission from digestate storage was considered to be equal to outside storage of pig manure (Table 3); emissions during the storage of end products were based on Mosquera et al. (2010) and scaled relative to the ratio of emission from raw manure storage, and storage of solid (42 times lower) and liquid fractions (12 times lower).

\subsubsection{Manure processing}

Separation of liquid manure and de-watering consumes electricity and chemicals for cleaning. Production emissions of these products were included in the assessment and taken from the ecoinvent database (EcoinventCentre, 2007). Electricity demand for processing was $9.0 \mathrm{kWh} \mathrm{ton}^{-1}$ manure entering the processing unit (Table 3). About 0.39 liters of flocculating additives (polyacrylamide) per ton of manure were used for 
separating solid particles from the liquid fraction. In addition, 0.022 liters of sodium hydroxide $(\mathrm{NaOH})$ and 0.081 liters of sulfuric acid $\left(\mathrm{H}_{2} \mathrm{SO}_{4}\right)$ per ton of manure was used for cleaning the installations (Hoeksma et al., 2011).

\subsubsection{Anaerobic digestion}

$\mathrm{AD}$ of the solid fraction was applied in PSc2 and CSc2. Digestion took place in a digester with a retention time of 60 days. The produced biogas was used in a combined heat and power plant (CHP) with an electric capacity of $250 \mathrm{kWh}$ (Zwart et al., 2006). The energetic and electric efficiencies of the CHP were respectively 80 and 35\% (Van der Leeden et al., 2003).

Emissions of $\mathrm{CH}_{4}, \mathrm{~N}_{2} \mathrm{O}$ and $\mathrm{NO}_{\mathrm{x}}$ and consumption of energy occurred during digestion and the combustion of the biogas. Methane losses were 1.5\% of produced $\mathrm{CH}_{4}$ (1\% from the installation and 0.5\% from the gas engine) (IPCC, 2006a).

Emissions of $\mathrm{N}_{2} \mathrm{O}$ were $0.1 \mathrm{~kg} \mathrm{~N}_{2} \mathrm{O} \mathrm{TJ}^{-1}$ of produced electricity and emissions of $\mathrm{NO}_{\mathrm{x}}$ were $0.42 \mathrm{~g} \mathrm{NO}_{\mathrm{x}} \mathrm{m}^{-3}$ of produced biogas (IPCC, 1997; VROM, 2010). Digestion required $66 \mathrm{MJ}$ of electricity per ton substrate and $166 \mathrm{MJ}$ heat per ton substrate (Berglund and Börjesson, 2006). Electricity was taken from the grid whereas heat originated from the CHP.

During AD the composition of solid fraction changed, as part of the organic nitrogen was converted into mineral nitrogen. To factor this in, we considered a $20 \%$ increase of $\mathrm{N}_{\min }$ during $\mathrm{AD}$ (Ovinge, 2008; Schröder et al., 2008).

\subsubsection{Distribution of products and transport distances}

Distribution of manure (flows a, b, and c in Fig. 1) in the reference situations (PRef; CRef) was calculated based on Dutch national statistics, an average defined arable and dairy farm, and legal application standards of $\mathrm{N}$ and $\mathrm{P}_{2} \mathrm{O}_{5}$. Of the arable farms, 57\% was on clay and $43 \%$ on sandy soil. For dairy farms these proportions were respectively $27 \%$ and $59 \%$ and additionally $14 \%$ was on peat soil. On the average arable farm, the total annual $\mathrm{N}, \mathrm{P}_{2} \mathrm{O}_{5}$, and $\mathrm{K}_{2} \mathrm{O}$ demand was: $179 \mathrm{~kg} \mathrm{~N} \mathrm{ha}^{-1}, 85 \mathrm{~kg}$ $\mathrm{P}_{2} \mathrm{O}_{5} \mathrm{ha}^{-1}$, and $171 \mathrm{~kg} \mathrm{~K}_{2} \mathrm{O}$ ha $^{-1}$ (De Vries et al., 2011). On the dairy farm, total annual $\mathrm{N}, \mathrm{P}_{2} \mathrm{O}_{5}$, and $\mathrm{K}_{2} \mathrm{O}$ demand was: $274 \mathrm{~kg} \mathrm{~N} \mathrm{ha}^{-1}$, $97 \mathrm{~kg} \mathrm{P}_{2} \mathrm{O}_{5} \mathrm{ha}^{-1}$, and $360 \mathrm{~kg}$ $\mathrm{K}_{2} \mathrm{O}$ ha ${ }^{-1}$. The legal application standards for animal manure applied on the arable 
farm were $170 \mathrm{~kg} \mathrm{~N} \mathrm{ha}^{-1}$ and $85 \mathrm{~kg} \mathrm{P}_{2} \mathrm{O}_{5} \mathrm{ha}^{-1}$ and on the dairy farm $250 \mathrm{~kg} \mathrm{~N}^{-1}$ and $100 \mathrm{~kg} \mathrm{P}_{2} \mathrm{O}_{5} \mathrm{ha}^{-1}$ (combined grassland and arable land) (MEAAI, 2010). Application amounts of $\mathrm{K}_{2} \mathrm{O}$ from animal manure were dependent on application limits of $\mathrm{N}$ and $\mathrm{P}_{2} \mathrm{O}_{5}$.

As a consequence of these limits, an average of 39\% of fattening pig manure on province level was transported and applied to another province in the Netherlands (external application) (CBS, 2011; De Vries et al., 2011). Additionally, 2.7\% of the surplus pig manure was exported outside the Netherlands and assumed to be applied in Northern France or Germany (Luesink, 2009 Personal communication). Exported manure was disinfected by heating it to 70 degrees $C$ and consumed approximately 24 kWh electricity per ton of manure (Melse et al., 2004). Emissions of nitrogen during disinfection were not considered as they were expected to contribute very little to the end result.

On average $13.8 \%$ of the dairy cattle manure on farm level was transported and applied to an external arable farm (De Vries et al., 2011). No export of cattle manure outside the Netherlands was assumed as this occurs rarely. Manure applied on farm was distributed relatively to the ratio of nitrogen applied to grassland (86\%) and arable land (14\%).

In the scenarios it was assumed that the MC was authorized to be used over and above the application standards of nitrogen from animal manure, but not over the total nitrogen application standards, to represent its possibility of being used as mineral fertilizer. All MC, therefore, was applied in the local area. In the pig manure scenarios 56\% was applied on grassland and 44\% on arable land (De Hoop et al., 2011). Mineral concentrate was applied first in the local area where after solid fraction or digestate was applied until one of the application standards was reached. The remainder was transported off farm and if necessary outside of the Netherlands

Transport distances were based on data from the manure processing plants (DR, 2010 Unpublished data) and expert judgment (Table 4). Emission data and resource use for all transportation were taken from the ecoinvent database (EcoinventCentre, 2007). Distances for application outside the Netherlands were estimated distances to Northern France and Germany. Transport distance of chemicals used for processing was $150 \mathrm{~km}$. 


\subsubsection{Manure product application and avoided fertilizer}

Manure, MC, and digestate were applied with a manure injector on grassland and arable land. Solid fraction was applied by means of a solid manure spreader and incorporated into the soil directly after application (arable land). Mineral fertilizer was applied with a broadcast spreader. The environmental impact from production and combustion of diesel and capital goods for spreading of the products were taken from the ecoinvent database (EcoinventCentre, 2007). All application areas were assumed to have similar management.

During and after application of manure and end products emissions of $\mathrm{NH}_{3}$, $\mathrm{N}_{2} \mathrm{O}$, $\mathrm{NO}$ and leaching of $\mathrm{NO}_{3}{ }^{-}$occurred (Table 3). Ammonia emission factors for the application of MC were adjusted relatively to emission factors for the application of manure. Absolute $\mathrm{NH}_{3}$ emissions for $\mathrm{MC}$ were recorded to be similar to manure (Huijsmans and Hol, 2010). Taking the higher mineral nitrogen content of MC into account, the emission factors of MC were calculated as 0.32 times the emission factor of manure (i.e., the ratio between the emission factor of liquid manure and MC).

Nitrous oxide emission factors for application of MC were adjusted in a similar way. Based on Velthof and Hummelink (2011), $\mathrm{N}_{2} \mathrm{O}$ emission factors from MC were 1.5 times the emission factor of manure. All nitrous oxide emission factors applied to grassland were weighted by soil type (i.e. the implementation of farms on different soils in section 2.3.5).

The nitrogen fertilizer replacement values (NFRVs, also called mineral fertilizer equivalent values) were used to calculate the avoided $\mathrm{N}$ fertilizer from using manure products (Table 3). For cattle manure applied on farms, NFRV was $45 \%$, as a consequence of grazing, and 60\% in the case of off farm application (DR, 2009). These ratios were applied to adjust replacement values for MC and solid fraction. Replacement values for pig and dairy cattle manure applied on arable farms were weighted by soil type. Fertilizer replacement values for $\mathrm{P}_{2} \mathrm{O}_{5}$ and $\mathrm{K}_{2} \mathrm{O}$ were considered as $100 \%$. Furthermore, the NFRV for undigested solid fraction was also used for digested solid fraction, since a recent study has indicated that the NFRV of digested manure increased in the first year after application but declined more rapidly afterwards and did not differ in the long term (Schröder et al., 2007).

In CSc1 and CSc2 over-application of $\mathrm{K}_{2} \mathrm{O}$ on farm occurred ( $0.57 \mathrm{~kg}$ total), so was assumed not to substitute mineral fertilizer. 
Nitrate leaching was computed as a percentage of the total $\mathrm{N}$ applied from each product. The leaching fractions for the products were based on N-balance calculations, i.e., after subtracting gaseous emission and $\mathrm{N}$-uptake by crops (Dekker et al., 2009). Leaching after application of the MC was considered equal to leaching from liquid fraction after separation of liquid manure. The leaching from digestate was considered equal to leaching from undigested solid fraction.

\subsection{Impact assessment}

In the life cycle impact assessment, the emissions and resource use from the references and scenarios are accounted for and categorized into the environmental impact categories to which they contribute (Heijungs et al., 1992). Five impact categories were selected based on their relevance for manure management: climate change (CC expressed in $\mathrm{kg} \mathrm{CO}_{2}$-equivalants (eq.), including emission of $\mathrm{CO}_{2}, \mathrm{CH}_{4}$, and $\mathrm{N}_{2} \mathrm{O}$ ), terrestrial acidification (TA expressed in $\mathrm{kg} \mathrm{SO}_{2}$-eq., including emission of $\mathrm{NH}_{3}, \mathrm{NO}_{\mathrm{x}}$, and $\mathrm{SO}_{2}$ ), marine eutrophication (ME expressed in $\mathrm{kg} \mathrm{N}$-eq., including emission of $\mathrm{NH}_{3}, \mathrm{NOx}$, and leaching of $\mathrm{NO}_{3}{ }^{-}$), particulate matter formation (PMF expressed in kg $\mathrm{PM}_{10}$-eq., including emission of particulates $<10 \mu \mathrm{m}$ and $\mathrm{NH}_{3}, \mathrm{NO}_{\mathrm{x}}$, and $\mathrm{SO}_{2}$ as precursors of particulate matter), and fossil fuel depletion (FFD expressed in kg oil-eq., with $42 \mathrm{MJ} \mathrm{kg}$ oil-eq ${ }^{-1}$ ). The scenarios and impact assessments were modeled and computed in SimaPro v.7.2 (PRé Consultants, the Netherlands) and by using the ReCiPe midpoint v.1.04 impact assessment method (Goedkooop et al., 2009).

\subsection{Sensitivity analysis}

A sensitivity analysis was conducted to assess the influence of changes in important parameters and underlying assumptions on the comparison between the scenarios and references and therewith the solidity of the end results. In the analyses, the effect of changing four parameters was tested: $\mathrm{CH}_{4}$ emission from manure storage, $\mathrm{NH}_{3}$ emission from manure processing, NFRV of MC, and excess heat utilization from AD. 


\section{Results}

\subsection{Environmental consequences of processing manure to produce mineral fertilizer}

The processing of pig manure and application of end products as fertilizer (PSc1) showed an increase in all environmental impact categories except for ME compared to the reference system. Climate change, FFD, TA, and PMF increased by respectively 9\%, 33\%, 19\%, and 23\% (Fig. 3). The increase in CC was caused mainly by emission of GHGs from storage of end products (Table 5). Although $\mathrm{CH}_{4}$ emission from manure storage decreased, storage of solid fraction resulted in higher $\mathrm{N}_{2} \mathrm{O}$ emissions from more denitrification compared to anaerobic storage of liquid manure (Table 3). Fossil fuel depletion increased as a result of energy demand for manure processing despite the energy demand for transportation having been approximately halved and avoided fossil fuel of mineral fertilizer produced. Less energy for transport was needed for two reasons. First, less weight had to be transported because water is removed during the process. Second, less long distance transport was required due to application of MC in the local area. TA and PMF increased due to $\mathrm{NH}_{3}$ emission from manure processing together with $\mathrm{NH}_{3}$ and $\mathrm{NO}_{\mathrm{x}}$ emission from product storage. Storage of solid fraction resulted in higher $\mathrm{NO}_{\mathrm{x}}$ emission. However, TA and PMF were governed by $\mathrm{NH}_{3}$ emission from manure storage prior to processing, which was equal in all cases.

Processing dairy cattle manure and applying the end products (CSc1) showed a decrease in CC of $67 \%$ and an increase in FFD of $110 \%$, in TA of 31\%, and in PMF of $44 \%$ compared to the reference situation (Fig. 4). ME did not change. The decrease in $\mathrm{CC}$ was caused by less $\mathrm{CH}_{4}$ emission from manure storage due to a shorter storage time, which was not offset by increased $\mathrm{N}_{2} \mathrm{O}$ emission from storage of solid fraction. Fossil fuel depletion increased as a result of energy demand for manure processing and transportation of manure and end products. Energy for transportation increased, because products had to be transported to and from the processing location whereas in the reference situation only surplus cattle manure was transported locally. TA and PMF in CSc1 increased for the same reasons as in PSc1. 


\subsection{Environmental consequences of processing manure to produce bio-energy}

The second scenario for pig and dairy cattle manure (PSc2 and CSc2) included the AD of solid fraction for bio-energy production. In PSc2, although TA and PMF increased due to higher $\mathrm{NH}_{3}$ emissions from manure processing and product storage, other measures mainly decreased. CC reduced $117 \%$ and FFD 59\% compared to the reference situation (Fig. 3). TA and PMF were lower compared to PSc1, as storage of solid fraction was avoided, but was higher (12\%) than in the reference situation. Again, ME did not change. Climate change and FFD reduced mainly due to substitution of fossil electricity (85 MJ) as a result of bio-energy production. Furthermore, CC reduced as a result of less $\mathrm{CH}_{4}$ emission from manure storage and less $\mathrm{N}_{2} \mathrm{O}$ emission from storage of solid fraction as it was assumed to be digested shortly after production (Table 5). Fossil fuel depletion reduced not only because of substituted fossil electricity, but also because of less energy for transport compared to PRef. The produced energy more than counteracted the required energy for processing.

Processing of dairy cattle manure and AD of solid fraction (CSc2) reduced CC by $104 \%$, but increased FFD by $19 \%$, TA by $9 \%$, and PMF by $12 \%$ compared to the reference situation. As in CSc1, ME did not change. Climate change decreased as a result of less $\mathrm{CH}_{4}$ emission from manure storage, less $\mathrm{N}_{2} \mathrm{O}$ emission from storage of solid fraction, and because of the substitution of fossil based electricity (56 MJ). FFD increased as a result of low energy production and energy demand for processing and transportation (Table 6). TA and PMF increased for the same reason as in CSc1.

\subsection{Sensitivity analysis}

\subsubsection{Methane emission from manure storage}

In this study we modeled $\mathrm{CH}_{4}$ emissions from manure storage specifically for the described circumstances. We assumed that storage time of manure was reduced to 1 month only in case of manure processing although in practical circumstances, even with manure processing, manure storage time might be longer. We therefore tested this assumption by exploring the effect of a 3 month storage time in the scenarios. Results showed an increase in CC for all scenarios (Table 7). In PSc1 and PSc2, CC was about $26 \mathrm{~kg} \mathrm{CO}_{2}$-eq higher than their baseline situations, whereas in CS1 and 
CSc2, this increase was about $78 \mathrm{~kg} \mathrm{CO}_{2}$-eq. For CSc1 and CSc2, this meant a change in the comparison between the scenarios and reference indicating the importance of shortening the storage time of manure to reduce CC. Furthermore, it shows the necessity of accurately estimating $\mathrm{CH}_{4}$ emission from manure storages in LCAs.

\subsubsection{Ammonia emission from manure processing}

In this study, we applied an estimated $\mathrm{NH}_{3}$ emission factor of $4 \%$ of $\mathrm{N}$ including both emission during storage of the end products (2\%) and emissions during manure processing (2\%) (Table 3). Data on $\mathrm{NH}_{3}$ emissions during processing are scarcely available, and therefore over or under estimation may occur. Since we considered testing a higher emission irrelevant, (as this would increase TA and PMF and to lesser extent ME and CC), a lower emission rate during processing ( $0.3 \%$ of $\mathrm{N}$ in manure entering the processing plant) was tested (Melse and Verdoes, 2005). Results showed a decrease in TA and PMF of approximately 10\% in CSc1, 13\% in CSc2 and a decrease of 7\% in both PSc1 and PSc2 (Table 7). The total impact for TA and PMF in PSc2 was approximately equal to the reference. The impact for CSc2 was even lower than its reference. This indicates that for improving the environmental performance of manure processing, controlling $\mathrm{NH}_{3}$ emission during processing is essential.

\subsubsection{NFRV of mineral concentrate}

The NFRV of MC has been reported to vary considerably depending on factors such as, soil type, method of application and weather conditions (Velthof, 2009). To assess the influence of a change in the NFRV on the impact assessment, this parameter was varied plus and minus 20\%. Results showed that mainly ME, CC and FFD decreased with a 20\% increase of the NFRV and increased with a $20 \%$ decrease of the NFRV (approximate variation for ME was 14\%, CC 29 - 265\%, and FFD 10 - 147\%).

\subsubsection{Excess heat utilization from anaerobic digestion}

The effect of including heat use of AD on the impact assessment was explored to represent existing initiatives of heat utilization. The substituted marginal source for heat in the Netherlands was assumed to be a mix of heat based on natural gas (79\%) and heat based on light fuel oil (21\%) (CBS, 2009; Menkveld and Beurskens, 2009). 
Heat from natural gas was divided into heat from boilers smaller than $100 \mathrm{~kW}$ with low $\mathrm{NO}_{\mathrm{x}}$ emission technology (55\%) and heat from industrial furnaces with low $\mathrm{NO}_{\mathrm{x}}$ emission technology (24\%) as these sources are the most common in the Netherlands (EcoinventCentre, 2007; Menkveld and Beurskens, 2009). Results showed a reduction in CC and FFD (respectively 118\% - 160\% and 26\% - 50\%) in the scenarios with AD (Table 7), thereby in CSc2, FFD was lower compared to the reference situation. This indicates that utilization of excess heat from AD strongly improves the environmental performance of manure management concerning CC and FFD.

\section{Discussion}

Overall, processing pig and dairy cattle manure to produce mineral fertilizer increased the environmental impact. In environmental terms, processing without AD does not represent an attractive alternative to current agricultural practice, as it increases FFD, CC, TA, and PMF. In the pig manure scenarios, the additional energy required for processing outweighed the reduction in energy required for transportation. This has also been observed in other studies (Lopez-Ridaura et al., 2009). In the cattle manure scenarios, even additional energy for transportation was needed. This indicates that other drivers e.g., economic viability or social acceptance, are more likely to propel initiatives for manure processing instead of the related environmental impact as considered in this study.

The importance of controlling nitrogen emissions from manure processing and product storage $\left(\mathrm{NH}_{3}, \mathrm{NO}_{\mathrm{x}}\right.$, and $\mathrm{N}_{2} \mathrm{O}$ ) is stressed by the modeled increases in CC, TA, and PMF, as environmental impact is affected both directly and indirectly due to less substituted mineral fertilizer. The importance of nutrient recovery for mineral fertilizer substitution has been indicated in other studies as well (Prapaspongsa et al., 2010). Furthermore, as Dinuccio et al. (2008) have mentioned, storing separated fractions from mechanical separation of manure has the potential to increase CC. Emission data from storage of separated fractions are still rare. These emissions are difficult to quantify as they depend on specific circumstances such as, storage type, storage time and climatologic conditions. Our initial estimates, therefore, were based on a combination of comparative lab results and best available data. Our model results show that it is important to further quantify these emissions under different conditions and include them in environmental assessments of manure management techniques. 
Processing pig manure and digestion of the solid fraction for bio-energy production presented a better alternative, as it added a strong environmental advantage by reducing CC and FFD. This is in agreement with other studies which showed a similar reduction in CC of approximately $40 \mathrm{~kg} \mathrm{CO}_{2}$-eq, including manure storage with a natural crust cover (Hamelin et al., 2011; Prapaspongsa et al., 2010). It also indicates that it is preferable to avoid producing end products with potentially high denitrification rates during storage as this results in increased CC. Furthermore, $\mathrm{AD}$ of the solid fraction from pig and cattle manure reduced TA and PMF compared to the scenarios without AD, as storage of solid fraction was avoided. However, TA and PMF remained higher compared to the references. This may be partly due to the assumption that $\mathrm{NH}_{3}$ emission factors, as a percentage of $\mathrm{N}_{\min }$, during application of digestate were assumed equal to undigested manure. The higher $\mathrm{N}_{\min }$ in the digestate, therefore, increased total $\mathrm{NH}_{3}$ emission. However, absolute emissions during application have been reported to be equal compared to undigested manure due to higher infiltration rates of digestate into the soil (Amon et al., 2006). In that case, including AD would lead to more reduction of TA and PMF improving its environmental potential compared to current practice.

Surprisingly, processing dairy cattle manure for bio-energy production did not lower FFD more than the reference. This indicates that processing of cattle manure in this fashion provides only little environmental benefit, reducing only CC. Moreover, the method presented in this research is costly with processing costs approximately 9 - 13 euro per ton of manure (De Hoop et al., 2011). Because cattle manure management differs strongly from pig manure management, simpler technologies requiring less energy may provide a better solution for handling cattle manure surpluses (Evers et al., 2010). Studies on the environmental consequences of such methods have not been conducted.

Compared to the references, in the scenarios ME did not change (maximum variation of 3\%). The main reason was that emissions of $\mathrm{NO}_{3}{ }^{-}, \mathrm{NO}_{\mathrm{x}}$, and $\mathrm{NH}_{3}$ counteracted each other in the different scenarios although they contribute in different degrees to ME, i.e., when emission of $\mathrm{NO}_{3}{ }^{-}$was lower, emissions of $\mathrm{NH}_{3}$ and $\mathrm{NO}_{\mathrm{x}}$ were higher and vice versa. This indicates that trade-off between different substances within an impact category may occur and require attention.

Important parameters affecting final results, as sensitivity analysis showed, include $\mathrm{CH}_{4}$ emission from manure storage, $\mathrm{NH}_{3}$ emission during processing, and the 
NFRV of the MC. Methane emission from manure storage has been reported elsewhere as an important parameter affecting the greenhouse gas balance and therewith CC from manure management systems (IPCC, 2006a; Lopez-Ridaura et al., 2009). Data on $\mathrm{CH}_{4}$ emission from manure storages should, therefore, be carefully considered, and it is advised to use models, as in this study, based on a higher Tier method in the IPCC guidelines to obtain specific data related to the circumstances of the conducted study. $\mathrm{NH}_{3}$ emission directly affects TA and PMF and to a lesser extent ME and CC and should therefore be kept to a minimum. This could be achieved by for example reducing contact with outside air, to ensure lower $\mathrm{NH}_{3}$ emission and overall equal or better performance compared to current practice. Furthermore, it shows the necessity of obtaining more detailed data on $\mathrm{NH}_{3}$ emissions, as well as other $\mathrm{N}$-substances, such as $\mathrm{N}_{2} \mathrm{O}, \mathrm{NO}$ and $\mathrm{N}_{2}$, occurring during processing to enhance LCA studies of manure management as very often emissions from processing may be underestimated. The NFRV of MC mainly affected ME, CC and FFD. It will depend on circumstances, such as soil type, weather conditions, cropping system, and time of application of the manure product. NFRVs used in calculating mineral fertilizer substitution rates should, therefore, be tailored to the specific conditions applicable over the long term. As Schröder et al. (2005) states, a correct assessment of the NFRV for each manure product is important in reducing the environmental impact of manure management in terms of $\mathrm{NO}_{3}{ }^{-}$leaching.

Marginal production of electricity was not addressed in the sensitivity analysis as recent studies have shown that a change in marginal electricity will not affect the outcome of the study (De Vries et al., 2011; Hamelin et al., 2011).

This study included $\mathrm{CH}_{4}, \mathrm{~N}_{2} \mathrm{O}$ and $\mathrm{NH}_{3}$ emissions from in house storage of manure as these emissions contribute strongly to CC, TA, and PMF. It also indicates that future work should consider the loss of $\mathrm{N}$ from manure storage prior to processing to determine a proper mineral fertilizer substitution rate. Additionally, although studies on reducing emissions from animal houses have been done e.g., (Aarnink et al., 1996; Canh et al., 1998; Monteny et al., 2006), new developments are needed, such as separating feces and urine under the slats (Aarnink and Ogink, 2007), and should be assessed to indicate improvements of the environmental performance of manure management.

As $\mathrm{N}$ and $\mathrm{P}$ application standards in the Netherlands will be lowered in the coming years to comply with the EU Nitrates Directive (MEAAI, 2010), local manure 
surpluses will likely increase, inducing more transportation of manure and its derived products. This, however, should not affect the conclusions of this study, as changing distribution and transport distances has only a limited effect on the environmental impact of manure management. Moreover, mineral fertilizer replacement rates may also change due to lowering of the application standards. The reference system, however, will also change in conjunction with those standards and, therefore, conclusions of this study will not change (i.e., the comparison between scenarios and references will stay the same). On the other hand, availability of other fertilization products could change fertilization strategies on farms and therewith the environmental impact. This should be studied in more detail as it was out of scope in this study.

Finally, future processing scenarios are also expected to include the processing of digestate from AD. Currently, however, this approach has practical difficulties as digestates vary in composition as a result of varying input materials and because processing conditions change from plant to plant (Hoeksma et al., 2011). It is expected that $\mathrm{AD}$ of liquid manure will increase energy production as compared to AD of the solid fraction and therewith further reduce CC (De Vries et al., 2011).

\section{Conclusion}

Processing of fattening pig and dairy cattle manure by using liquid and solid separation and reverse osmosis (RO) to produce mineral fertilizer increased overall environmental impact in terms of climate change (CC) (except for dairy cattle manure), terrestrial acidification (TA), particulate matter formation (PMF), and fossil fuel depletion (FFD) compared to current agricultural practice. Marine eutrophication (ME) did not change. Adding the production of bio-energy enhanced the environmental performance by substituting fossil electricity and reducing storage emissions from solid fraction. Utilization of excess heat increased this trend for CC and FFD. However, the addition of AD did not present a better option compared to current practice considering TA and PMF, and FFD for cattle manure, unless when $\mathrm{NH}_{3}$ emissions from processing were kept low. In that case, equal or better environmental performance was obtained for TA and PMF. 
Key parameters affecting the environmental performance were identified as $\mathrm{NH}_{3}$ emission from manure processing and product storage together with $\mathrm{N}_{2} \mathrm{O}$ and $\mathrm{NO}_{\mathrm{x}}$ emissions from product storage as a result of denitrification; controlling these was essential to reduce the environmental impact of manure processing and to improve the potential for substituting mineral fertilizer. Additionally, $\mathrm{CH}_{4}$ emission from manure storage should be modeled as precisely as possible to the circumstances being studied, to correctly assess its environmental consequences. Overall, this emphasizes a continuous need of real time measurements of these emissions to 'feed' future LCA studies.

Results of this study show the environmental consequences and key parameters affecting the environmental impact of manure management as it considers the full life cycle of the processing and application of all end products. It also shows that innovations that appear worthwhile for reducing environmental impact do not always deliver the expected results when considering all consequences within the system. Furthermore, it highlights the importance of particular emissions during both processing and storage. For those tackling environmental problems around manure management, this assessment has provided a number of key outcomes to inform their decision making.

\section{Acknowledgements}

This study was financed as a part of the research project 'Pilots Mineralenconcentraten (BO-12.02-006-002)' initiated by the Dutch ministries of Economic Affairs, Agriculture and Innovation and Infrastructure and Environment, and the agricultural industry. We would like to thank our colleagues at SDU (Marianne Wesnæs, Lorie Hamelin and Henrik Wenzel) and DTU (Alessio Boldrin, David Tonini and Thomas Astrup) for their useful comments in an early stage of this research. We thank Linda McPhee (Linda McPhee Consulting) for technical correction of the manuscript.

\section{References}

Aarnink, A.J.A., Ogink, N.W.M., 2007. Environmental impact of daily removal of pig manure with a conveyer belt system, International Symposium on Air Quality and Waste Management for Agriculture, Broomfield, Colorado, USA. 
Aarnink, A.J.A., van den Berg, A.J., Keen, A., Hoeksma, P., Verstegen, M.W.A., 1996. Effect of Slatted Floor Area on Ammonia Emission and on the Excretory and Lying Behaviour of Growing Pigs. Journal of Agricultural Engineering Research 64, 299-310.

Amon, B., Kryvoruchko, V., Amon, T., Zechmeister-Boltenstern, S., 2006. Methane, nitrous oxide and ammonia emissions during storage and after application of dairy cattle slurry and influence of slurry treatment. Agriculture, Ecosystems \& Environment 112, 153-162.

Berglund, M., Börjesson, P., 2006. Assessment of energy performance in the life-cycle of biogas production. Biomass and Bioenergy 30, 254-266.

Burton, C.H., Turner, C., 2003. Manure management: Treatment strategies for sustainable agriculture (second. ed.). Silsoe Research Institute, Bedford, UK.

Canh, T.T., Aarnink, A.J.A., Schutte, J.B., Sutton, A., Langhout, D.J., Verstegen, M.W.A., 1998.

Dietary protein affects nitrogen excretion and ammonia emission from slurry of growing-finishing pigs. Livestock Production Science 56, 181-191.

CBS, 2009. Het energieverbruik voor warmte afgeleid uit de Energiebalans. Statistics Netherlands, The Hague/ Heerlen, the Netherlands.

CBS, 2011. Animal manure key figures; production, transport, and application. Statistics Netherlands, The Hague/ Heerlen, the Netherlands. http://statline.cbs.nl/StatWeb/ (accessed Aug 8, 2011).

De Hoop, J.G., Daatselaar, C.H.G., Doornewaard, G.J., Tomson, N.C., 2011. Mineralenconcentraten uit mest: Economische analyse en gebruikerservaringen uit de pilots mestverwerking in 2009 en 2010.

Agricultural Economics Institute (LEI). Report 2011-030, The Hague, the Netherlands.

De Mol, R.M., Hilhorst, M.A., 2003. Methaan-, lachgas- en ammoniakemissie bij productie, opslag en transport van mest. IMAG, Instituut voor Milieu- en Agritechniek, Wageningen, the Netherlands. De Vries, J.W., Corré, W.J., Van Dooren, H.J.C., 2010. Environmental assessment of untreated manure use, manure digestion and co-digestion with silage maize. Wageningen UR Livestock Research, Report 372, Lelystad, the Netherlands.

De Vries, J.W., Hoeksma, P., Groenestein, C.M., 2011. Life Cycle Assessment Mineral Concentrates Pilot. Wageningen UR Livestock Research. Report 480, Lelystad, the Netherlands.

Dekker, P.H.M., Stilma, E.S.C., van Geel, W.C.A., Kool, A., 2009. Levenscyclusanalyse meststoffen bij gebruik in de biologische en gangbare landbouw. Praktijkonderzoek Plant en Omgeving, Wageningen University \& Research Centre, Lelystad, The Netherlands.

Dinuccio, E., Berg, W., Balsari, P., 2008. Gaseous emissions from the storage of untreated slurries and the fractions obtained after mechanical separation. Atmospheric Environment 42, 2448-2459.

DR, 2009. Mestbeleid 2008 - 2009 tabellen. Dienst Regelingen van het Ministerie van Landbouw,

Natuur en Voedselkwaliteit, Den Haag.

DR, 2010 Unpublished data. Gegevens aangeleverd ten behoeve van het onderzoek LCA mineralenconcentraten. Transportdata 2009 van de pilotbedrijven mineralenconcentraten. Dienst Regeleningen, Assen.

Dumont, M., 2010. Groen Gas. Symposium industriële vergisting. NL Agency, The Hague, the Netherlands. http://www.energyvalley.nl/attachments/22215_Agenschap_NL_industriele_vergisting_2 0 okt 2010.pdf (accessed Aug 8, 2011).

EcoinventCentre, 2007. Ecoinvent data v2.0 Final reports econinvent 2007. Swiss Centre for Life Cycle Inventories, Dübendorf, Switzerland.

Evers, A.G., De Haan, M.H.A., De Buisonjé, F.E., Verloop, K., 2010. Perspectieven mestscheiding op melkveebedrijven. Wageningen UR Livestock Research \& Plant Research International, Report 421, Lelystad, the Netherlands.

Goedkooop, M., Heijungs, R., Huijbregts, M.A.J., de Schryver, A., Struijs, J., van Zelm, R., 2009.

ReCiPe 2008. A life cycle impact assessment method which comprises harmonised category indicators at the midpoint and endpoint level. First edition. Ministry of Spatial Planning and Environment (VROM), The Hague, the Netherlands.

Groenestein, C.M., Huijsmans, J.F.M., Velthof, G.L., Van Bruggen, C., 2011. Ammonia emission factors for livestock housing and manure storages in the Netherlands based on total ammoniacal nitrogen. Submitted to Biosystems Engineering.

Hamelin, L., Wesnæs, M., Wenzel, H., Petersen, B.M., 2011. Environmental Consequences of Future Biogas Technologies Based on Separated Slurry. Environmental Science \& Technology, 5869-5877. Heijungs, R., Guinée, J.B., Huppes, G., Lankreijer, R.M., Udo de Haes, H.A., Wegener-Sleeswijk, A., Ansems, A.M.M., Eggels, P.G., 1992. Environmental Life Cycle Assessment of Products, I Guide, II Backgrounds. Centre of Environmental Sciences, Leiden, the Netherlands.

Hoeksma, P., Buisonjé, F.E.d., Ehlert, P.H.I., Horrevorts, J.H., 2011. Mineral concentrates from animal slurry. Monitoring of the pilot production plants. Wageningen UR Livestock Research, Lelystad, the Netherlands.

Huijsmans, J.F.M., Bussink, D.W., Groenestein, C.M., Velthof, G.L., Vermeulen, G.J., 2011. Ammonia emission factors for field applied manure, fertilizers and grazing in the Netherlands. Submitted to Atmospheric Environment.

Huijsmans, J.F.M., Hol, J.M.G., 2010. Ammoniakemissie bij toediening van concentraat op beteeld bouwland en grasland. Plant Research International, Report 387, Wageningen.

Huijsmans, J.F.M., Mosquera, J., Hol, J.M.G., 2007. Ammoniakemissie bij het uitrijden van vaste mest. Deskstudie. Plant Research International B.V., Report 155, Wageningen, the Netherlands.

IEA, 2008. World Energy Outlook 2008. International Energy Agency, Paris, France.

IEA, 2011. Electricity/ Heat in Netherlands in 2008. International Energy Agency, Paris, France.

IPCC, 1997. Revised 1996 IPCC guidelines for national greenhouse gas emission inventories. IPCC, Geneva, Switzerland. 
IPCC, 2006a. Emissions from livestock and manure management, Guidelines for National Greenhouse Gas Inventories, Geneva, Switzerland.

IPCC, 2006b. Good Practice Guidance and Uncertainty Management in National Greenhouse Gas Inventories. Intergovernmental Panel on Climate Change, Geneva, Switzerland.

ISO-14040, 2006. Environmental Management - Life Cycle Assessment - Principles and Framework. International Organisation for Standardisation (ISO), Geneva.

KWIN, 2009-2010. Kwantitatieve Informatie Veehouderij 2009-2010. Wageningen UR Liverstock Research, Lelystad, the Netherlands.

Lopez-Ridaura, S., Werf, H.v.d., Paillat, J.M., Le Bris, B., 2009. Environmental evaluation of transfer and treatment of excess pig slurry by life cycle assessment. Journal of Environmental Management 90, 1296-1304.

Luesink, H., 2009 Personal communication. Manure markets and mineral fertilizer products, The Hague, the Netherlands.

MEAAI, 2010. Fourth action programme nitrate directive (2010 - 2013). Ministry of Economic Affairs, Agriculture and Innovation, The Hague, the Netherlands.

Melse, R.W., De Buisonjé, F.E., Verdoes, N., Willers, H.C., 2004. Quick scan be- en verwerkingstechnieken voor dierlijke mest. Animal Sciences Group, Lelystad, the Netherlands. Melse, R.W., Verdoes, N., 2005. Evaluation of Four Farm-scale Systems for the Treatment of Liquid Pig Manure. Biosystems Engineering 92, 47-57.

Menkveld, M., Beurskens, L., 2009. Duurzame warmte en koude in Nederland, Policy development for improving RES-H/C penetration in European Member States (RES-H Policy). Energy Research Centre of the Netherlands, Petten, the Netherlands.

Monteny, G.-J., Bannink, A., Chadwick, D., 2006. Greenhouse gas abatement strategies for animal husbandry. Agriculture, Ecosystems \& Environment 112, 163-170.

Mosquera, J., Schils, R.L.M., Groenestein, C.M., Hoeksma, P., Velthof, G.L., Hummelink, E., 2010.

Emissies van lachgas, methaan en ammoniak uit mest na scheiding. Wageningen UR Livestock Research, Report 427, Lelystad, the Netherlands.

Oenema, O., Velthof, G.L., Verdoes, N., Groot Koerkamp, P.W.G., Monteny, G.J., Bannink, A., van der Meer, H.G., van der Hoek, K.W., 2000. Forfaitaire waarden voor gasvormige stikstofverliezen uit stallen en mestopslagen. Alterra, Wageningen, the Netherlands.

Ovinge, J., 2008. Biogas Flevoland. Agro Milieu Coöperatie voor boer \& bodem (AMCBB), Lelystad, the Netherlands.

Prapaspongsa, T., Christensen, P., Schmidt, J.H., Thrane, M., 2010. LCA of comprehensive pig manure management incorporating integrated technology systems. Journal of Cleaner Production 18, 14131422.

Sandars, D.L., Audsley, E., Cañete, C., Cumby, T.R., Scotford, I.M., Williams, A.G., 2003.

Environmental Benefits of Livestock Manure Management Practices and Technology by Life Cycle Assessment. Biosystems Engineering 84, 267-281.

Schröder, J., 2005. Revisiting the agronomic benefits of manure: a correct assessment and exploitation of its fertilizer value spares the environment. Bioresource Technology 96, 253-261.

Schröder, J., Uenk, D., Hilhorst, G., 2007. Long-term nitrogen fertilizer replacement value of cattle manures applied to cut grassland. Plant and Soil 299, 83-99.

Schröder, J.J., van Middelkoop, J.C., van Dijk, W., Velthof, G.L., 2008. Quick scan stikstofwerking van dierlijke mest. Actualisering van kennis en de mogelijke gevolgen van aangepaste forfaits. Wettelijke Onderzoekstaken Natuur \& Milieu, WOt-rapport 85. Wageningen Universiteit, Wageningen, the Netherlands.

Stehfest, E., Bouwman, L., 2006. $\mathrm{N}_{2} \mathrm{O}$ and $\mathrm{NO}$ emission from agricultural fields and soils under natural vegetation: summarizing available measurement data and modeling of global annual emissions. Nutrient Cycling in Agroecosystems 74, 207-228.

Thomassen, M.A., van Calker, K.J., Smits, M.C.J., I lepema, G.L., de Boer, I.J.M., 2008. Life cycle assessment of conventional and organic milk production in the Netherlands. Agricultural Systems 96, 95-107.

Timmerman, M., van Riel, J.W., Bisschops, I., van Eekert, M., 2009. Optimaliseren van mestvergisting. Animal Sciences Group, Lelystad, the Netherlands.

Van der Leeden, R.H.C., Van Roovert, P.P.M.J., Van de Wassenberg, A.H.M., 2003. Mestvergisting op boerderijniveau. Vergunninglevering en haalbaarheid van vergisting van mest en biomassa. HAS Kennis Transfer, 's-Hertogenbosch, the Netherlands.

Van Dooren, H.J.C., 2010 Unpublished data. Biogas production from solid fraction. Wageningen UR Livestock Research, Wageningen, the Netherlands.

Velthof, G.L., 2009. Kunstmestvervangers onderzocht. Tussentijds rapport van het onderzoek in het kader van de pilots Mineralenconcentraten. Alterra, Wageningen UR, Wageningen, the Netherlands. Velthof, G.L., Hummelink, E., 2011. Ammoniak- en lachgasemissie bij toediening van mineralenconcentraten. Resultaten van labaratoriumproeven in het kader van de Pilot Mineralenconcentraten. Alterra, Wageningen, the Netherlands.

Velthof, G.L., Mosquera, J., 2010. Calculation of nitrous oxide emission from agriculture in the Netherlands; update of emission factors and leaching fraction. Alterra, Wageningen, the Netherlands. VROM, 2010. Besluit emissie-eisen middelgrote stookinstallaties milieubeheer. Ministerie van Housing Environment and Spacial Planning, The Hague, the Netherlands.

Weidema, B., Frees, N., Nielsen, A.M., 1999. Marginal production technologies for life cycle inventories. The International J ournal of Life Cycle Assessment 4, 48-56. 
Wesnæs, M., Wenzel, H., Petersen, B.M., 2009. Life Cycle Assessment of Slurry Management Technologies. Department of Agroecology and Environment, Faculty of Agricultural Sciences, Aarhus University, Aarhus, Denmark.

Zwart, K.B., Oudendag, D.A., Ehlert, P.A.I., Kuikman, P.J., 2006. Duurzaamheid co-vergisting van dierlijke mest. Alterra Report 1437, Wageningen University and Research Centre, Wageningen, the Netherlands. 


\section{Figures}

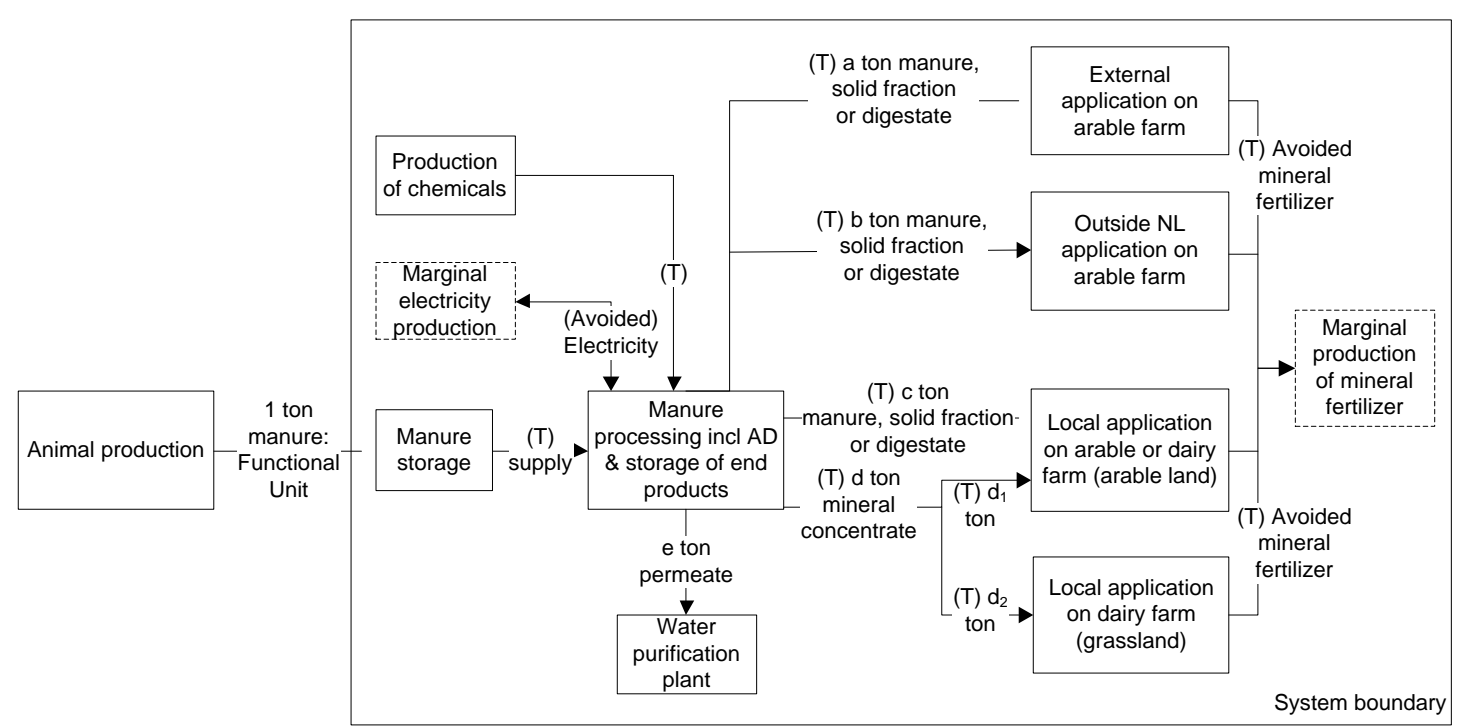

Fig. 1. Manure management system with input of 1 ton pig or dairy cattle manure and distribution of end products as considered in the assessment. Black arrows represent mass flows of materials. The two-way arrow for electricity production and consumption points out that electricity is consumed as well as produced. (T) represents transportation.

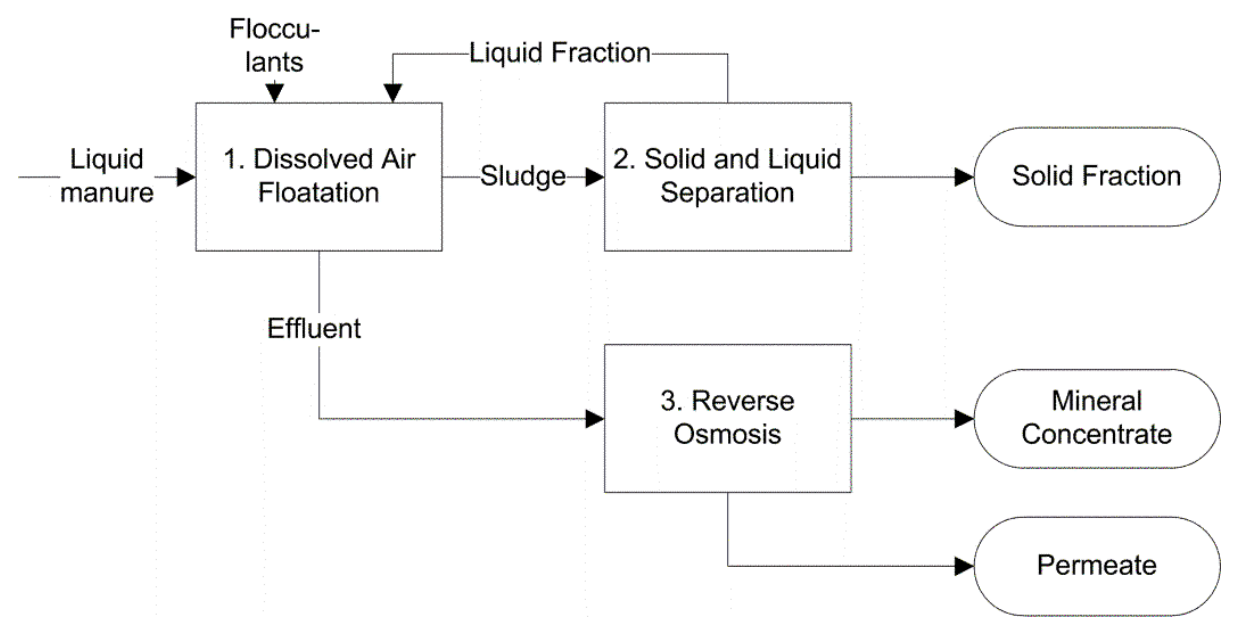

Fig. 2. Schematic overview of the manure processing technology and its intermediate and end products (after Hoeksma et al. (2011)). 


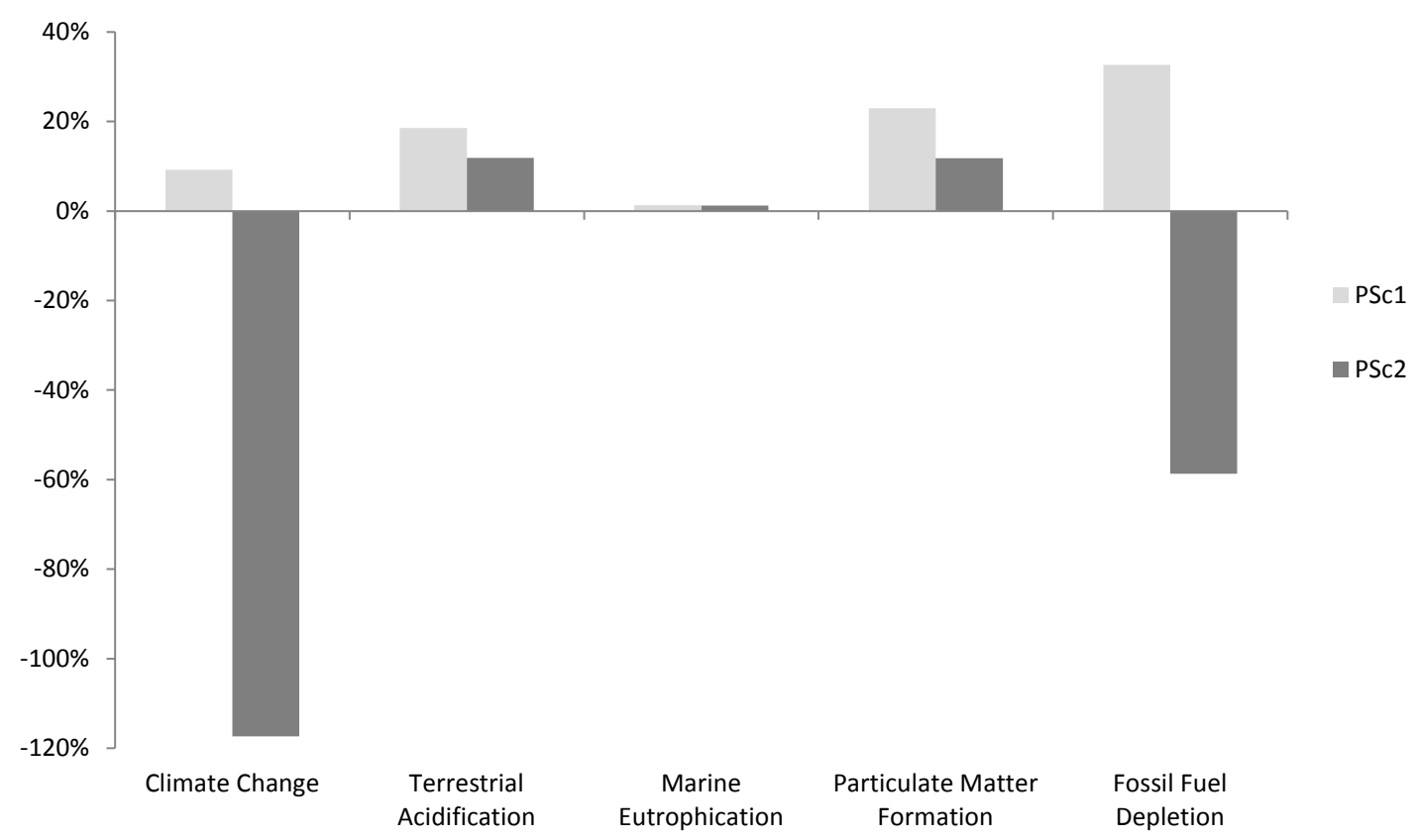

Fig. 3. Relative change in the environmental impact of the fattening pig manure scenarios (PSc1 \& PSc2) compared to the reference (PRef = 0\%).

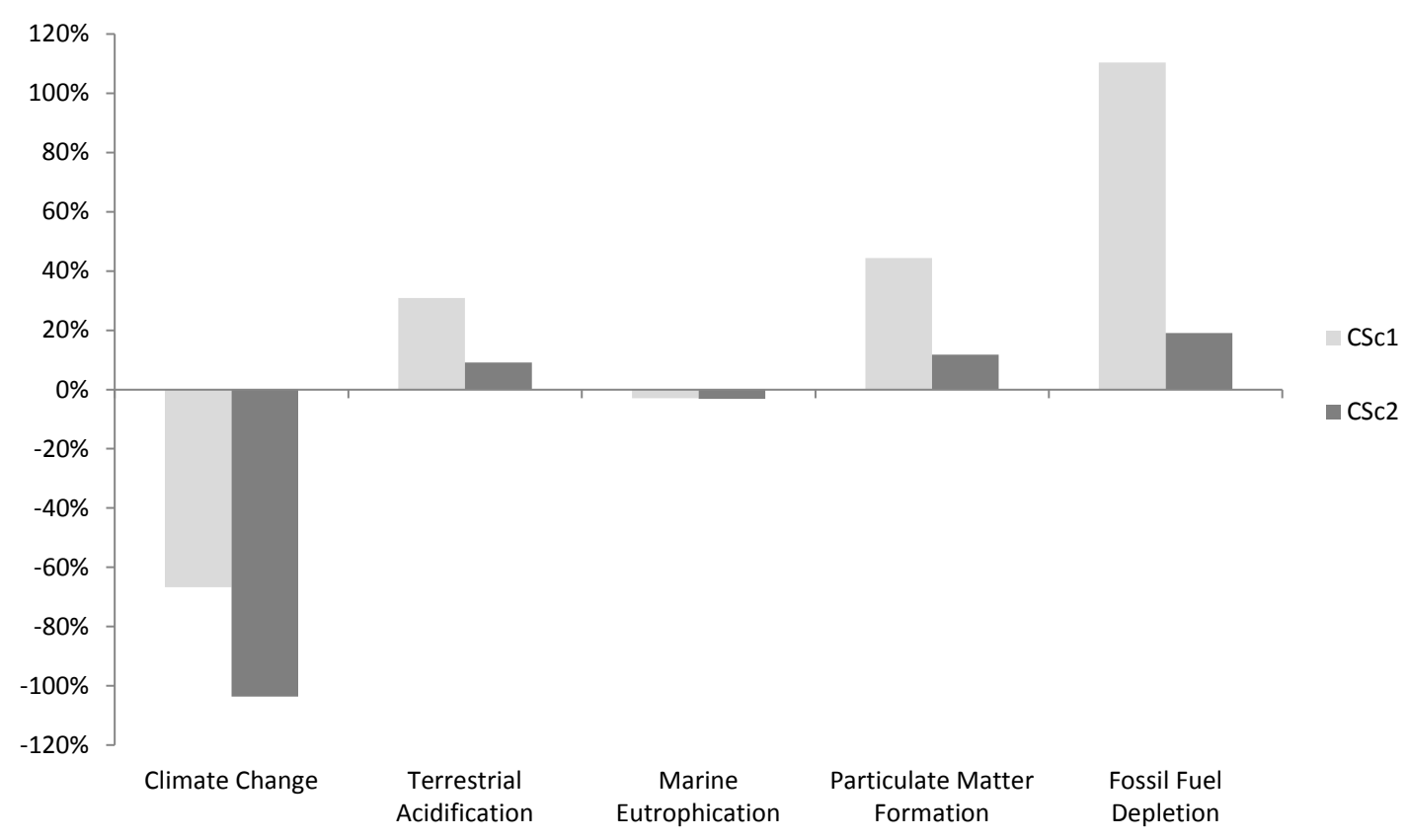

Fig. 4. Relative change in the environmental impact of the dairy cattle manure scenarios (CSc1 \& CSc2) compared to the reference (CRef $=0 \%$ ). 
Table 1. Considered processes in the references and manure processing scenarios for pig and dairy cattle manure

\begin{tabular}{lcccccc}
\hline Scenario & $\begin{array}{c}\text { Storage in } \\
\text { house }\end{array}$ & $\begin{array}{c}\text { Outside } \\
\text { storage }\end{array}$ & $\begin{array}{c}\text { Manure } \\
\text { processing }\end{array}$ & $\begin{array}{c}\text { Anaerobic } \\
\text { digestion }\end{array}$ & $\begin{array}{c}\text { Product } \\
\text { storage }\end{array}$ & $\begin{array}{c}\text { Field } \\
\text { application }\end{array}$ \\
\hline Pig & & & & & & \\
PRef & $\mathrm{X}$ & $\mathrm{X}$ & - & - & - & $\mathrm{X}$ \\
PSc1 & $\mathrm{X}$ & - & $\mathrm{X}$ & - & $\mathrm{X}$ & $\mathrm{X}$ \\
PSc2 & $\mathrm{X}$ & - & $\mathrm{X}$ & $\mathrm{X}$ & $\mathrm{X}$ & $\mathrm{X}$ \\
\hline Cattle & & & & & & \\
CRef & $\mathrm{X}$ & - & - & - & - & $\mathrm{X}$ \\
CSc1 & $\mathrm{X}$ & - & $\mathrm{X}$ & - & $\mathrm{X}$ & $\mathrm{X}$ \\
CSc2 & $\mathrm{X}$ & - & $\mathrm{X}$ & $\mathrm{X}$ & $\mathrm{X}$ & $\mathrm{X}$ \\
\hline PRef & & & - & & &
\end{tabular}

PRef = pig manure reference, PSc1 = pig manure scenario 1, PSc2 = pig manure scenario 2, CRef = dairy cattle manure reference, CSc1 = dairy cattle manure scenario $1, \mathrm{CSc} 2$ = dairy cattle manure scenario 2 . ' $\mathrm{X}$ ' indicates included processes whereas '' indicates excluded processes. 
Table 2. Calculated distribution of mass and nutrients for processing and chemical composition of manure and end products after storage

\begin{tabular}{|c|c|c|c|c|c|c|c|c|c|c|}
\hline \multirow[t]{2}{*}{ Product } & \multicolumn{3}{|c|}{ Distribution of mass and nutrients ${ }^{b}$} & \multicolumn{7}{|c|}{ Chemical composition } \\
\hline & $\begin{array}{l}\text { Mass } \\
(\%)\end{array}$ & $\begin{array}{l}\mathrm{OM} \\
(\%)\end{array}$ & $\mathrm{N}, \mathrm{N}_{\min }, \mathrm{P}, \mathrm{K}(\%)$ & $\begin{array}{c}\text { DM } \\
\left(\operatorname{kg~ton~}^{-1}\right)\end{array}$ & $\begin{array}{c}\text { OM } \\
\left(\mathrm{kg} \mathrm{ton}^{-1}\right)\end{array}$ & $\begin{array}{c}\mathrm{N}_{\text {tot }} \\
\left(\mathrm{kg} \mathrm{ton}^{-1}\right)\end{array}$ & $\begin{array}{c}\mathrm{N}_{\min } \\
\left(\mathrm{kg} \mathrm{ton}^{-1}\right)\end{array}$ & $\begin{array}{c}\mathrm{P}_{2} \mathrm{O}_{5} \\
\left(\mathrm{~kg} \mathrm{ton}^{-1}\right)\end{array}$ & $\begin{array}{c}\mathrm{K}_{2} \mathrm{O} \\
\left(\mathrm{kg} \mathrm{ton}^{-1}\right)\end{array}$ & $\begin{array}{l}\text { Density } \\
\left(\mathrm{kg} \mathrm{m}^{-3}\right)\end{array}$ \\
\hline PM after storage ${ }^{a}$ & - & - & - & 90.0 & 60.0 & 7.60 & 4.60 & 4.2 & 7.2 & 1040 \\
\hline $\begin{array}{l}\text { PM after in house } \\
\text { storage }\end{array}$ & - & - & - & 90.4 & 60.4 & 7.63 & 4.63 & 4.2 & 7.2 & 1040 \\
\hline PM after excretion & - & - & - & 93.7 & 63.7 & 9.34 & 6.01 & 4.2 & 7.2 & 1040 \\
\hline Mineral concentrate & 39 & 12 & $53,70,5,79$ & 27.1 & 18.1 & 9.90 & 7.77 & 0.5 & 14.7 & 1031 \\
\hline Solid fraction & 19 & 88 & $45,28,95,19$ & 416 & 278 & 14.9 & 3.68 & 20.8 & 7.2 & n.d. \\
\hline Permeate & 42 & 0 & $2,3,0,1$ & 0.17 & 0.11 & 0.32 & 0.27 & 0.0 & 0.2 & 1001 \\
\hline Digested solid fraction & - & - & - & 351 & $213^{\mathrm{C}}$ & 17.1 & 7.25 & 20.8 & 7.2 & n.d. \\
\hline CM $_{\text {after storage }}{ }^{\mathrm{a}}$ & - & - & - & 86.0 & 64.0 & 4.40 & 2.20 & 1.6 & 6.2 & 1005 \\
\hline CM after excretion & - & - & - & 92.3 & 70.3 & 4.66 & 2.22 & 1.6 & 6.2 & 1005 \\
\hline Mineral concentrate & & & & 25.8 & 19.2 & 5.71 & 3.65 & 0.2 & 12.6 & 1031 \\
\hline Solid fraction & & ial $\mathrm{t}$ & g manure & 395 & 294 & 8.58 & 3.03 & 7.9 & 6.2 & n.d. \\
\hline Permeate & & & & 0.16 & 0.12 & 0.18 & 0.07 & 0.0 & 0.2 & 1001 \\
\hline Digested solid fraction & - & - & - & 352 & 251 & 9.89 & 3.36 & 7.9 & 6.2 & n.d. \\
\hline
\end{tabular}

‘'‘ = not applicable, n.d. = not determined. $\mathrm{OM}=$ organic matter, $\mathrm{DM}=$ dry matter, $\mathrm{N}_{\text {tot }}=$ total nitrogen, $\mathrm{N}_{\min }=$ mineral nitrogen $\left(\mathrm{NH}_{4}{ }^{+}\right.$-N), $\mathrm{PM}$

= pig manure, and $\mathrm{CM}=$ cattle manure. 
a (KWIN, 2009-2010).

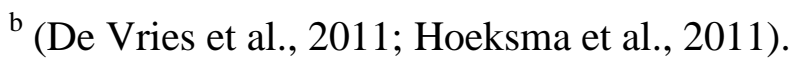

${ }^{\mathrm{c}}$ Calculated based on 50\% $\mathrm{C}$ in the organic matter, $37.5 \mathrm{~m}^{3} \mathrm{CH}_{4}$ ton $^{-1}$ solid fraction and a $\mathrm{CH} 4$ content of $60 \%$ in the biogas. Includes storage losses after digestion $\left(0.17 \mathrm{~kg} \mathrm{CH}_{4} \mathrm{ton}^{-1}\right)$. 
Table 3. Emission factors and energy use during storage, processing, and field application of manure and end products and methane yields of anaerobically digested solid fractions

\begin{tabular}{|c|c|c|c|c|c|c|c|c|c|c|c|c|c|c|c|c|c|}
\hline & \multirow[t]{3}{*}{ Unit } & \multicolumn{2}{|c|}{$\begin{array}{c}\text { Storage in } \\
\text { house }\end{array}$} & \multirow{3}{*}{$\begin{array}{c}\begin{array}{c}\text { Outside } \\
\text { storage }\end{array} \\
\text { PM }\end{array}$} & \multicolumn{2}{|c|}{$\begin{array}{c}\text { Processing/ } \\
\text { AD }\end{array}$} & \multicolumn{3}{|c|}{ Product storage } & \multicolumn{8}{|c|}{ Field application } \\
\hline & & $\mathrm{PM}$ & $\mathrm{CM}$ & & PM & $\mathrm{CM}$ & $\mathrm{MC}$ & Dig & SF & \multicolumn{2}{|c|}{ PM, CM, Dig } & \multicolumn{2}{|c|}{ AN } & \multicolumn{2}{|c|}{$\mathrm{MC}$} & \multicolumn{2}{|c|}{ SF } \\
\hline & & & & & & & & & & $\mathrm{Gr}$ & $\mathrm{Ar}$ & $\mathrm{Gr}$ & $\mathrm{Ar}$ & $\mathrm{Gr}$ & $\mathrm{Ar}$ & $\mathrm{Gr}$ & $\mathrm{Ar}$ \\
\hline $\mathrm{NH}_{3}-\mathrm{N}$ & $\%$ TAN & $27^{\mathrm{a}}$ & $10^{\mathrm{a}}$ & $2 \% \mathrm{~N}^{\mathrm{a}}$ & \multicolumn{5}{|c|}{$4 \% \mathrm{~N}$} & $19^{\mathrm{i}}$ & $2^{i}$ & \multicolumn{2}{|c|}{$2.5^{i}$} & $6.0^{\mathrm{i}}$ & $0.64^{i}$ & $40^{i}$ & $22^{i}$ \\
\hline $\mathrm{N}_{2} \mathrm{O}-\mathrm{N}$ & $\% \mathrm{~N}$ & \multicolumn{3}{|c|}{$0.1^{\mathrm{a}}$} & \multicolumn{2}{|c|}{-} & - & $0.1^{\mathrm{b}}$ & $2^{a}$ & $0.4^{\mathrm{j}}$ & $1.3^{j}$ & $1.3^{\mathrm{j}}$ & $1^{j}$ & $0.6^{j}$ & $1.95^{j}$ & $0.4^{\mathrm{j}}$ & $1.3^{j}$ \\
\hline $\mathrm{N}_{2}-\mathrm{N}$ & $\% \mathrm{~N}$ & \multicolumn{3}{|c|}{$1^{\mathrm{a}}$} & \multicolumn{2}{|c|}{-} & - & $1^{\mathrm{C}}$ & $10^{\mathrm{C}}$ & - & - & - & - & - & - & - & - \\
\hline NO-N & $\% \mathrm{~N}$ & \multicolumn{3}{|c|}{$0.1^{\mathrm{a}}$} & \multicolumn{2}{|c|}{-} & - & $0.1^{\mathrm{C}}$ & $2^{\mathrm{C}}$ & \multicolumn{8}{|c|}{$0.55^{\mathrm{k}}$} \\
\hline $\mathrm{NO}_{3}-\mathrm{N}$ & $\% \mathrm{~N}$ & - & - & - & \multicolumn{2}{|c|}{-} & - & - & - & \multicolumn{2}{|c|}{$20.3^{1}$} & \multicolumn{2}{|c|}{$15.8^{\top}$} & & $3.1^{1}$ & \multicolumn{2}{|c|}{$22.6^{1}$} \\
\hline $\mathrm{NFRV}^{\mathrm{a}}$ & $\%$ & - & - & - & \multicolumn{2}{|c|}{-} & - & - & - & \multicolumn{2}{|c|}{$62 ; 45^{\mathrm{m}}$} & \multicolumn{2}{|c|}{$100^{\mathrm{m}}$} & $60^{\mathrm{m}}$ & $60 ; 80^{\mathrm{m}}$ & $31^{\mathrm{m}}$ & $31 ; 41^{\mathrm{m}}$ \\
\hline $\mathrm{CH}_{4 \text { long }}{ }^{\mathrm{a}}$ & $\mathrm{kg} \operatorname{ton}^{-1}$ & $1.33^{\mathrm{d}}$ & $3.32^{\mathrm{d}}$ & \multirow{2}{*}{$0.17^{\mathrm{d}}$} & \multicolumn{2}{|c|}{ - } & \multirow{2}{*}{$0.014^{\mathrm{e}}$} & \multirow{2}{*}{$0.17^{\mathrm{d}}$} & \multirow{2}{*}{$0.004^{\mathrm{e}}$} & - & - & - & - & - & - & - & - \\
\hline $\mathrm{CH}_{4 \text { short }}{ }^{\mathrm{a}}$ & $\mathrm{kg} \operatorname{ton}^{-1}$ & $0.29^{\mathrm{d}}$ & $0.21^{\mathrm{d}}$ & & \multicolumn{2}{|c|}{-} & & & & - & - & - & - & - & - & - & - \\
\hline $\mathrm{CH}_{4}$ yield & $m^{3}$ ton $^{-1}$ & - & - & - & $37.5^{\mathrm{f}}$ & $25^{\mathrm{f}}$ & - & - & - & - & - & - & - & - & - & - & - \\
\hline Energy & $\mathrm{kWh}$ ton $^{-1}$ & \multicolumn{2}{|c|}{$1.7^{\mathrm{g}}$} & $0.5^{\mathrm{g}}$ & & $0^{h}$ & & & - & & & & coin & t data & $\operatorname{ase}^{n}$ & & \\
\hline
\end{tabular}

'‘ = not included. $\mathrm{AD}$ = anaerobic digestion, $\mathrm{PM}=$ pig manure, $\mathrm{CM}=$ cattle manure, $\mathrm{MC}=$ mineral concentrate, Dig = digestate, $\mathrm{SF}=$ solid fraction, $\mathrm{AN}=$ ammonium nitrate, $\mathrm{Gr}=$ grassland, $\mathrm{Ar}=$ arable land, $\mathrm{TAN}=$ total ammoniacal nitrogen $\left(\mathrm{NH}_{4}{ }^{+}\right.$and $\left.\mathrm{NH}_{3}\right)$, $\mathrm{NFRV}=$ nitrogen fertilizer replacement value, $\mathrm{CH}_{4}$ long $=$ methane emission factor for long term (3 months) storage, and $\mathrm{CH}_{4}$ short $=$ methane emission factor for short term (1 month) storage. 
a (Groenestein et al., 2011).

b (IPCC, 2006b).

${ }^{\mathrm{c}} \mathrm{N}_{2}-\mathrm{N}$ and NO-N emission factors calculated as ratio of $\mathrm{N}_{2} \mathrm{O}-\mathrm{N}$ (Oenema et al., 2000).

d (De Mol and Hilhorst, 2003).

e (Mosquera et al., 2010).

${ }^{\mathrm{f}}$ Solid fraction from fattening pig manure (Timmerman et al., 2009). Solid fraction from dairy cattle manure (Van Dooren, 2010 Unpublished data).

g (Wesnæs et al., 2009).

${ }^{\mathrm{h}}$ Energy requirement for processing (De Vries et al., 2011).

i (Huijsmans et al., 2011; Huijsmans and Hol, 2010; Huijsmans et al., 2007).

${ }^{\mathrm{j}}$ (Velthof and Hummelink, 2011; Velthof and Mosquera, 2010).

${ }^{\mathrm{k}}$ (Stehfest and Bouwman, 2006).

${ }^{\mathrm{l}}$ (Dekker et al., 2009).

m (De Vries et al., 2011; DR, 2009)

n (EcoinventCentre, 2007). 
Table 4. Transport distances and method of transportation in the references and scenarios

\begin{tabular}{lccccc}
\hline Scenario & $\begin{array}{c}\text { Supply of } \\
\text { manure } \\
(\mathrm{km})\end{array}$ & $\begin{array}{c}\text { Supply of } \\
\text { mineral } \\
\text { fertilizer }(\mathrm{km})\end{array}$ & $\begin{array}{c}\text { Local } \\
\text { transport } \\
(\mathrm{km})\end{array}$ & $\begin{array}{c}\text { External } \\
\text { transport } \\
(\mathrm{km})\end{array}$ & $\begin{array}{c}\text { Outside NL } \\
\text { transport } \\
(\mathrm{km})\end{array}$ \\
\hline PRef & - & & $31^{\mathrm{a}}$ & $120^{\mathrm{a}}$ & $200^{\mathrm{b}}$ \\
PSc1\&2 & $13.9^{\mathrm{a}}$ & $50^{\mathrm{b}}$ & $31^{\mathrm{a}}$ & $120^{\mathrm{a}}$ & $200^{\mathrm{b}}$ \\
CRef & - & & $1^{\mathrm{b}}$ & $50^{\mathrm{b}}$ & - \\
CSc1\&2 & $13.9^{\mathrm{a}}$ & & $13.9^{\mathrm{a}}$ & $50^{\mathrm{b}}$ & - \\
\hline Transport & Lorry $>32$ & Lorry 16-32 & Lorry $>32$ & Lorry $>32$ & Lorry 16 - 32 \\
method & ton & ton & ton & ton & ton \\
\hline
\end{tabular}

'-‘ = not included.

a (DR, 2010 Unpublished data).

${ }^{\mathrm{b}}$ Estimated transport distances. One km distance in CRef with tractor and trailer. 
Table 5. Impact assessment results for the life cycle stages in the pig manure reference and scenarios

\begin{tabular}{|c|c|c|c|c|c|c|c|c|c|}
\hline & Total ${ }^{*}$ & $\begin{array}{l}\text { Manure } \\
\text { storage }\end{array}$ & $\begin{array}{l}\text { Manure processing } \\
\text { \& product storage }\end{array}$ & $\begin{array}{c}\text { Anaerobic } \\
\text { digestion }\end{array}$ & $\begin{array}{c}\text { Manure } \\
\text { application }\end{array}$ & $\begin{array}{c}\text { MC } \\
\text { application }\end{array}$ & $\begin{array}{c}\text { Solid fraction/ } \\
\text { digestate application }\end{array}$ & $\begin{array}{l}\text { Avoided } \\
\text { fertilizer }\end{array}$ & Transport \\
\hline \multicolumn{10}{|c|}{ Climate change (kg CO${ }_{2}$-eq) } \\
\hline PRef & 33.8 & 51.0 & - & - & 51.2 & - & - & -75.7 & 7.2 \\
\hline PSc1 & 36.9 & 19.9 & 42.0 & - & - & 25.1 & 20.8 & -74.8 & 3.8 \\
\hline PSc2 & -5.9 & 19.9 & 12.4 & -12.9 & - & 25.1 & 23.1 & -77.2 & 3.8 \\
\hline \multicolumn{10}{|c|}{$\begin{array}{l}\text { Terrestrial acidification } \\
\left(\mathrm{kg} \mathrm{SO}_{2} \text {-eq) }\right.\end{array}$} \\
\hline PRef & 5.0 & 5.3 & - & - & 0.31 & - & - & -0.65 & 0.03 \\
\hline PSc1 & 5.9 & 4.8 & 0.99 & - & - & 0.36 & 0.33 & -0.62 & 0.02 \\
\hline PSc2 & 5.6 & 4.8 & 0.91 & -0.02 & - & 0.36 & 0.11 & -0.64 & 0.02 \\
\hline \multicolumn{10}{|c|}{$\begin{array}{l}\text { Marine eutrophication } \\
\text { (kg N-eq) }\end{array}$} \\
\hline PRef & 0.93 & 0.21 & - & - & 1.5 & - & - & -0.80 & 0.01 \\
\hline PSc1 & 0.95 & 0.19 & 0.10 & - & - & 0.73 & 0.67 & -0.76 & 0.01 \\
\hline PSc2 & 0.95 & 0.19 & 0.05 & -0.01 & - & 0.73 & 0.76 & -0.79 & 0.01 \\
\hline \multicolumn{10}{|c|}{$\begin{array}{l}\text { Particulate matter formation } \\
\left(\mathrm{kg} \mathrm{PM}_{10} \text {-eq) }\right.\end{array}$} \\
\hline PRef & 0.62 & 0.69 & - & - & 0.06 & - & - & -0.15 & 0.01 \\
\hline PSc1 & 0.76 & 0.63 & 0.15 & - & - & 0.05 & 0.05 & -0.14 & 0.01 \\
\hline PSc2 & 0.69 & 0.63 & 0.12 & -0.01 & - & 0.05 & 0.02 & -0.14 & 0.01 \\
\hline \multicolumn{10}{|c|}{ Fossil fuel depletion (kg oil-eq) } \\
\hline PRef & -6.4 & 0.53 & - & - & 0.62 & - & - & -10.3 & 2.8 \\
\hline PSc1 & -4.3 & 0.48 & 3.4 & - & - & 0.18 & 0.21 & -10.0 & 1.5 \\
\hline PSc2 & -10.2 & 0.48 & 3.4 & -5.5 & - & 0.18 & 0.09 & -10.2 & 1.5 \\
\hline
\end{tabular}


Table 6. Impact assessment results for the life cycle stages in the cattle manure reference and scenarios

\begin{tabular}{|c|c|c|c|c|c|c|c|c|c|}
\hline & Total $^{*}$ & $\begin{array}{l}\text { Manure } \\
\text { storage }\end{array}$ & $\begin{array}{l}\text { Manure processing } \\
\& \text { product storage }\end{array}$ & $\begin{array}{c}\text { Anaerobic } \\
\text { digestion }\end{array}$ & $\begin{array}{c}\text { Manure } \\
\text { application }\end{array}$ & $\begin{array}{c}\text { MC } \\
\text { application }\end{array}$ & $\begin{array}{c}\text { Solid fraction/ } \\
\text { digestate application }\end{array}$ & $\begin{array}{l}\text { Avoided } \\
\text { fertilizer }\end{array}$ & Transport \\
\hline \multicolumn{10}{|c|}{$\begin{array}{l}\text { Climate change ( } \mathrm{kg} \mathrm{CO}_{2-} \\
\text { eq) }\end{array}$} \\
\hline CRef & 69.0 & 87.0 & - & - & 19.0 & - & - & -37.7 & 0.7 \\
\hline CSc1 & 22.9 & 9.2 & 27.9 & - & - & 10.5 & 6.9 & -34.0 & 2.2 \\
\hline CSc2 & -2.5 & 9.2 & 11.1 & -7.7 & - & 10.5 & 7.0 & -34.8 & 2.2 \\
\hline \multicolumn{10}{|c|}{$\begin{array}{l}\text { Terrestrial acidification } \\
\left(\mathrm{kg} \mathrm{SO}_{2} \text {-eq) }\right.\end{array}$} \\
\hline CRef & 1.4 & 0.67 & - & - & 0.99 & - & - & -0.29 & 0 \\
\hline CSc1 & 1.8 & 0.67 & 0.58 & - & - & 0.24 & 0.56 & -0.27 & 0.01 \\
\hline CSc2 & 1.5 & 0.67 & 0.53 & -0.01 & - & 0.24 & 0.33 & -0.28 & 0.01 \\
\hline \multicolumn{10}{|c|}{$\begin{array}{l}\text { Marine eutrophication } \\
\text { (kg N-eq) }\end{array}$} \\
\hline CRef & 0.61 & 0.03 & - & - & 0.95 & - & - & -0.37 & 0 \\
\hline CSc1 & 0.60 & 0.03 & 0.07 & - & - & 0.42 & 0.40 & -0.33 & 0 \\
\hline CSc2 & 0.59 & 0.03 & 0.03 & 0 & - & 0.42 & 0.45 & -0.34 & 0 \\
\hline \multicolumn{10}{|c|}{$\begin{array}{l}\text { Particulate matter formation } \\
\left(\mathrm{kg} \mathrm{PM}_{10} \text {-eq) }\right.\end{array}$} \\
\hline CRef & 0.16 & 0.09 & - & - & 0.14 & - & - & -0.07 & 0 \\
\hline CSc1 & 0.24 & 0.09 & 0.09 & - & - & 0.04 & 0.08 & -0.06 & 0 \\
\hline CSc2 & 0.18 & 0.09 & 0.07 & 0 & - & 0.04 & 0.05 & -0.06 & 0 \\
\hline \multicolumn{10}{|c|}{ Fossil fuel depletion (kg oil-eq) } \\
\hline CRef & -3.9 & 0.48 & - & - & 0.46 & - & - & -5.1 & 0.26 \\
\hline CSc1 & 0.4 & 0.48 & 3.4 & - & - & 0.18 & 0.21 & -4.8 & 0.84 \\
\hline CSc2 & -3.1 & 0.48 & 3.4 & -3.3 & - & 0.18 & 0.08 & -4.8 & 0.84 \\
\hline
\end{tabular}

'- = not included, ${ }^{*}$ Totals do not always correspond to the sum of columns due to rounding. 
Table 7. Results of the sensitivity analysis for the tested parameters

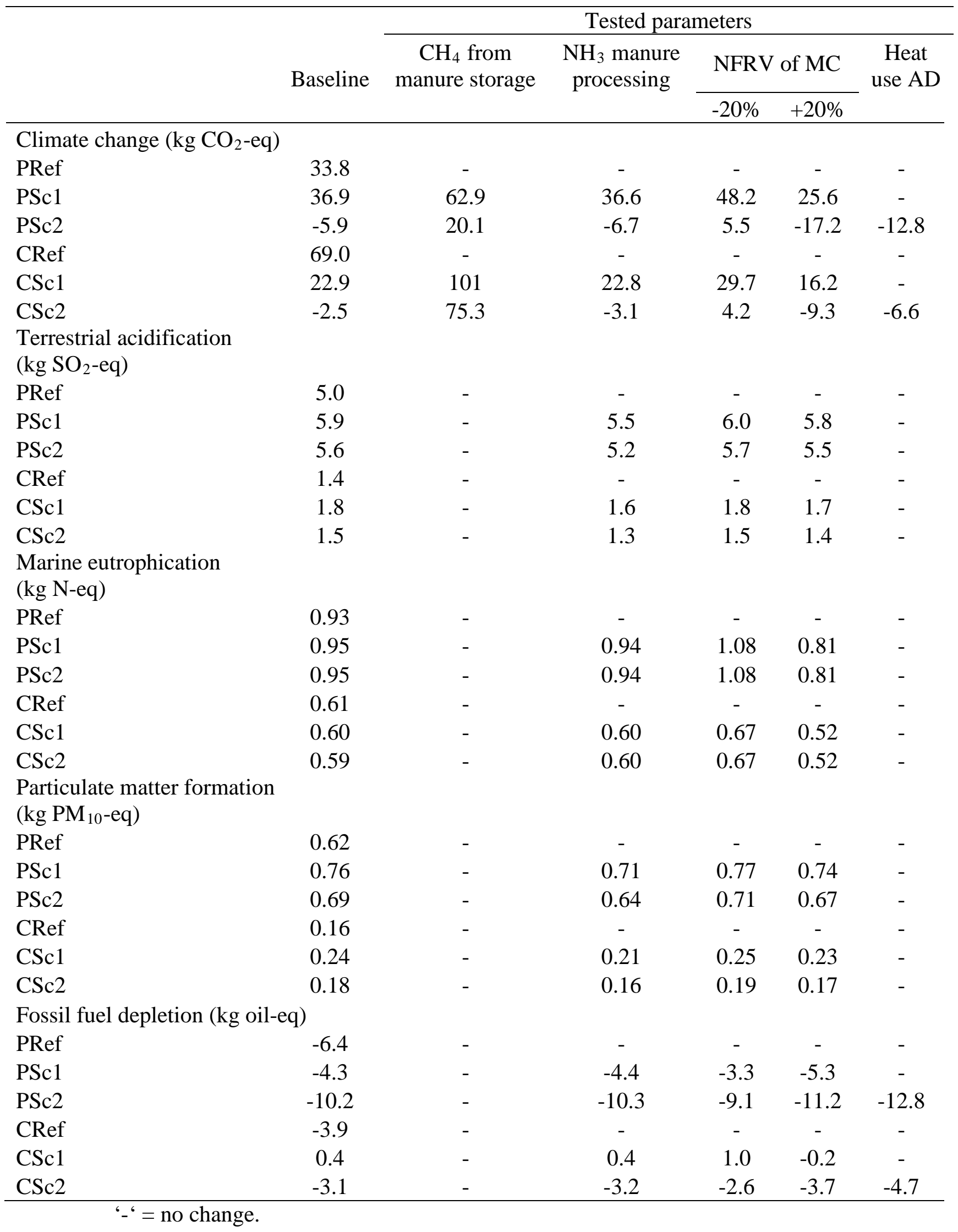

